\title{
The Effects of Pigweed Redroot (Amaranthus retoflexus) Weed COMPETITION AND ITS ECONOMIC THRESHOLDS IN CORN (Zea mays) ${ }^{1}$
}

\author{
Nível de Dano Econômico do Caruru (Amaranthus retroflexus) na Cultura do Milho \\ (Zea mays) \\ VAZIN, F.
}

\begin{abstract}
The aim of this study was to determine the economic damage threshold of Pigweed redroot for corn regarding its density. An experiment was conducted at the_Agriculture Research station of Islamic Azad University branch of Gonabad during 2006. The experiment was carried out as a factorial in a randomized complete block design with three replications. In the experiments, the factors included corn (var. 704) densities of 7.5, 8.5 and 9.5 plants $\mathrm{m}^{-2}$ and pigweed redroot densities of 0, 2, 4, 6 and 8 plants $\mathrm{m}^{-2}$. The increase in Pigweed redroot density, decrease in crop grain and biomass yield components such as ear length, ear diameter, number of grains per row, row number, grain number in ear, grain yield and biological yield of $\mathrm{corn}_{2}$ decreased. Also, with an increase in corn density, the number of grain per rows, row number, grain yield and biological yield of corn increased. The economic thresholds density of Pigweed redroot was 0.09 to 0.13 plants $\mathrm{m}^{-2}$ in corn different densities, and increased with corn density increases.
\end{abstract}

Keywords: economic thresholds, weed competition, pigweed redroot, corn

\begin{abstract}
RESUMO - O objetivo deste estudo foi determinar o nível de dano econômico do caruru na cultura do milho em funçẫo das densidades do milho e do caruru. O experimento foi conduzido na Agriculture Research Station of Islamic Azad University, em Gonabad. O delineamento experimental foi de blocos casualizados em esquema fatorial com três repetições. Os fatores incluiram densidades do milho (var. 704) de 7,5, 8,5 e 9,5 plantas $m^{-2}$ e densidades do caruru de 0, 2, 4, 6 e 8 plantas $m^{-2}$. $O$ aumento na densidade de caruru diminui o número de grãos da cultura e os componentes de produção de biomassa, tais como comprimento e diâmetro da espiga, número de grãos por linha, número de grãos na espiga, o rendimento de grãos e o rendimento biológico do milho. Além disso, com o aumento na densidade de milho, o número de grãos por linha, o rendimento de grãos e o rendimento biológico de milho aumentaram. O nível de dano econômico do caruru foi alcançado com 0,09-0,13 plantas $\mathrm{m}^{-2}$ em diferentes densidades de milho.
\end{abstract}

Palavras-chave: nível de dano econômico, competição de plantas daninhas, densidade.

\section{INTRODUCTION}

Weed control is known as an essential measure in all systems of agricultural farming. Since the existence of weed impact on the yield quantity and quality, the harvesting cost, variety, and abundance of pest and useful insects decreased. For this purpose, farmers spend huge amounts of money for decreasing the harmful effects of weeds on agricultural crops, and the serious damage that farmers bear due to a lack of sufficient weed control signifies the importance of this issue. Based on the conducted studies, the failure to control weeds will result in a $10-30 \%$ (Kropff et al., 1993) decrease in the crop plant yield depending on the weed competitive capability. On the other hand, despite intense

1 Recebido para publicação em 6.8.2011 e aprovado em 27.7.2012.

Vazin, farshid, Islamic Azad University,Gonabad branch, Gonabad, Iran,<farshidvazin@gmail.com>. 
controlling exerted on most agricultural systems, weed competition caused a 10 percent decrease in crops' production (Kropff et al., 1993).

The results indicated that, in some circumstances, changes of some factors such as crop plant density, row distances, planting date, amount of nitrogen, etc. can tip the crop plant-weed balance in favor of the crop plant. This fact depends on being conscious of the mutual environmental effects of weeds and their response to the management of cropping ecosystems (Aguyoh, 2003). In addition to the introduction of Amaranthus retoflexus and Echinochloa crus-galli as the most popular species of weed in corn and soy fields, soy average yield declines from 45 and 50\% were reported, respectively, due to the separate competition of soy with each of those two weeds. Moreover, a corn yield drop of 5$45 \%$ was reported due to the rivalry with Amaranthus retoflexus at densities of 1 to 12 plants/row meter (Bensch, 2003). In another research study, a corn yield decrease of $86-90 \%$ was reported because of the competition with Amaranthus retoflexus (Dawn, 2004). Massinga et al. (2001) reported that densities of 0.5-8 weeds per row meter caused an $11-91 \%$ corn yield drop. Delay in the germination of weeds resulted in the fact that the yield drop rate decreased to 7-35\%. Joesph (2004) concluded that corn yield losses dropped from $58 \%$ to $19 \%$ by a delay in the germination of Amaranthus retoflexus. Jerry et al. (2004) reported a 1.8-3.5\% Sorghum bicolor yield drop by adding one weed plant per 15 row meter. Massinga et al. (2004) reported that an increase in the density of Amaranthus retoflexus led to decreases of the corn grain yield and forage yield of $11-74 \%$ and $1-44 \%$, respectively. According to Weaver (1994), economic damage threshold density is defined as a weed density in which the profit resulting from weed control equals the control cost. If the weed density is less than the threshold, then no method is suggested for weed control. Lawrence et al. (2006) reported the economic damage threshold of Amaranthus retoflexus between 0.3-1.4 plant $\mathrm{m}^{-2}$. The goal of this investigation was to examine the effect of Pigweed redroot on the yield and yield components of corn.

\section{MATERIAL AND METHODS}

The experiment was conducted at the research field of the Islamic Azad University, Gonabad Branch in the cropping year of 2006. The examined factors consisted of a pigweed redroot density of $2,4,6$, and 8 plant $\mathrm{m}^{-2}$ and corn densities of $7.5,8.5$, and 9.5 plant $\mathrm{m}^{-2}$. The corn genotype used in the experiment was SC704. The experiment was conducted in a factorial arrangement based on a Randomized Completed Block Design (RCBD) with three replications. In this experiment, control treatments including corn monocropping associated with weed control in different densities of corn and Pigweed redroot monocropping were considered per block in order to estimate the corn yield in competitionfree conditions and also to realize the growth rate and productive power of Pigweed redroot in competition-free conditions. The length and width of each plot was 6 and 5 meters, respectively. Each plot included 6 rows with inter row spacing of $75 \mathrm{~cm}$ and intra row spacing of $10.7,11.6$, and $12.7 \mathrm{~cm}$ for $7.5,8.5$, and 9.5 corn plants $\mathrm{m}^{-2}$, respectively. The seeds of Pigweed redroot were exposed to water for 24 hours and were cultivated with high density at a depth of $0.5 \mathrm{~cm}$ and then were planted at a distance of $5 \mathrm{~cm}$ away from the crop plant (Hartzler et al., 2004). For weed densities of 2, 4,6 , and 8 plants $\mathrm{m}^{-2}$, the distances between weeds were $50,25,16.6$, and $12.5 \mathrm{~cm}$, respectively. After obtaining assurance of the establishment of Pigweed redroot plants, they were thinned between the 2- leaf and 4- leaf stages of maize growth. All the operations of crop management were carried out according to the recommended stages for corn cultivation. On the $84^{\text {th }}$ and $98^{\text {th }}$ days after planting, the layer distribution of the species' leaf area was measured by measuring the leaf area index in 9 layers of $20 \mathrm{~cm}(0-20,20-40$, 40-60, 60-80, 80-100, 100-120, 120-140, 140$160,160-180 \mathrm{~cm}$ from soil level). For this reason, the plants in each sample were divided into $20 \mathrm{~cm}$ layers, and the leaves in each layer were separated. Then, the areas of leaves were determined. All the plant samples were taken from $30 \mathrm{~cm}$ of the inner four rows. Before harvesting, 5 plants were chosen randomly from each plot (4 middle rows) and the stem diameter, number of ear/plant, diameter and 
length of the ear, number of rows and grains / ear and number of grains on the corn row were measured. A one hundred-seed weight was obtained based on three randomized samplings of the product of each plot in gram. The grain yields of the two middle rows were measured by the omission of 1 meter of margins of both their sides in kilogram and based on $14 \%$ moisture. In order to calculate the shoot biomass production, the plants, whose yield had been determined, were weighed and 100-gram samples of them were dried in an oven at $70{ }^{\circ} \mathrm{C}$. After that, their moisture percentages were determined. Last, the shoot dry matter was weighed and the biological yield was obtained from the totality of the shoot dry matter weight and grain yield (zero percent moisture). Following that, the harvest index was calculated in percentage from the ratio of grain yield and biological yield. The Cousens (1985) three-parameter equation was applied in order to determine the effect of various densities of Redroot Pig weed on the economic yield and biological yield of corn as follows:

$$
Y=Y_{w f}\left(\frac{1-I * D}{1-\left(1+\frac{I+D}{A}\right)}\right)
$$

where $\mathrm{Y}_{\mathrm{wf}}=$ Yield in weed-free conditions; I= Yield drop due to each individual plant of weed when density approaches zero; A= Maximum yield loss when weed density approaches infinity; $\mathrm{D}=$ Weed density (one plant $\mathrm{m}^{-2}$ ).

Cousens (1985) two-parameter hyperbolic equation was used in order to determine the relationship between the weed density and yield loss and then the loss yield percentage was calculated.

$$
Y_{l=} \frac{I * D}{1+\frac{I * D}{A}}
$$

where $\mathrm{Y}_{l}=$ Yield loss of harvest plant (percentage).

Afterwards, the economic damage threshold of Pigweed redroot was determined through the model presented by O'Donavan (1991), which is as follows:

$$
D=\frac{1-\left(\frac{Y P-H}{Y P}\right)}{\frac{I}{100}+\left(\frac{I}{A}\right)\left(\frac{Y P-H}{Y P}-1\right)}
$$

The economic damage threshold of Pigweed redroot was determined based on the following assumptions:

The price of each kilogram of corn (Parameter $\mathrm{P}$ in the equation) was assumed equivalent to 1.20 USD. The cost of Pigweed redroot control per hectare (Parameter $\mathrm{H}$ ) was taken as equivalent to 25 USD per hectare.

$\mathrm{D}=$ Economic damage threshold density; $\mathrm{P}=$ Price of one kilogram of corn in USD; Y= Yield in weed-free conditions (kilogram hectare ${ }^{-1}$ ); $\mathrm{H}=$ Herbicide purchase and application cost (USD hectare ${ }^{-1}$ ).

Crop growth rate (CGR) has been calculated as follows:

$$
\mathrm{CGR}=\left(\mathrm{w}_{2}-\mathrm{w}_{1}\right) / \mathrm{SA}\left(\mathrm{t}_{2}-\mathrm{t}_{1}\right)
$$

where CGR is the Crop growth rate expressed in gr $\mathrm{m}^{-2}$ day $^{-1} \cdot \mathrm{w}_{1}$ and $\mathrm{w}_{2}$ are crop dry weight at the beginning and end of intervals, $t_{1}$ and $t_{2}$ are corresponding days, and SA is the land area occupied by plants at each sampling (Brown et al., 1991).

These relative growth rate (RGR) values can be calculated using the following formula and are expressed as gr gr ${ }^{-1}$ day $^{-1}$.

$$
\operatorname{RGR}=(1 / w) \times(d w / d t)
$$

where $\mathrm{w}$ is the dry weight and $\mathrm{dw} / \mathrm{dt}$ is the change in dry weight per unit time (Brown et al., 1991).

EXCEL, SAS, and Sigmaplot softwares were employed for conducting statistical calculations and designing diagrams.

\section{RESULT AND DISCUSSION}

\section{The effects of pigweed redroot weed competition on the economic yield of corn}

Corn density and Pigweed redroot density have significant effects on corn grain yield. The increase in the corn density led to a corn grain yield increase (Table 1). Cousens (1985) three-parameter equation was utilized in 
order to determine the effects of different densities of Pigweed redroot on grain yield. The results indicated that by increasing the density of Pigweed redroot, corn grain yield decreased significantly $(\mathrm{P}<0.01)$ (Tables 1$)$. The parameters obtained from the model suggested that increasing corn density caused a decrease of the yield loss percentage resulting from each individual plant of Pigweed redroot (Parameter I). Furthermore, it led to a decrease in the maximum yield loss due to the high densities of Pigweed redroot (Parameter A) (Table 2). Each individual Pigweed redroot plant in different densities of $7.5,8.5$, and 9.5 corn plants $\mathrm{m}^{-2}$ caused corn economic yield decreases of $10.8,9.6$, and 7.4 percent, respectively.

\section{Biological yield}

An increase in the corn density resulted in an increase of the biological yield of corn (Table 1). The parameters of the model (Table 2 ) indicate that an increase in the corn density resulted in a boost of the maximum yield $\left(\mathrm{Y}_{\mathrm{wf}}\right)$ estimated based on the model as well. On the other hand, an increase in the corn density caused a decrease of the biological yield loss resulting from each individual Pigweed redroot plant (I). An increase in the corn density caused the decline of the maximum yield loss resulting from high densities of Pigweed redroot (A). Due to an increase in the density of Pigweed redroot, the biological yield of corn declined (Table 1).

\section{The effect of pigweed redroot weed competition on other corn yield components}

Pigweed redroot density had a significant effect on maize length, maize diameter, number of grains per maize, number of rows, and number of grains per row, but it had no significant effect on 100-grain weight and the harvest index (Table 1). An increase in the Pigweed redroot density resulted in the decline of maize length and maize diameter, which might be due to the limitation of growth space and intense competition with corn for gaining light, water, plant nutrition, and other growth limiting factors. The maximum and minimum maize length and diameter, respectively, were observed in the weed-free treatment of corn $(17.6$ and $5.86 \mathrm{~cm})$ and 8 plants of Pigweed redroot in a square meter $(15.6$ and $5.55 \mathrm{~cm})$. There is a significant difference in the number of rows, number of grains/row, and number of grains/maize between the weedfree treatment of corn and other treatments. The minimum amounts of these traits in the treatment of 8 plant $\mathrm{m}^{-2}$ of Pigweed redroot were $28.9,36.5$, and 1054.85 , respectively.

The effect of corn plantation density on the number of grains / row and the number of rows was significant (Table 1) and it had no

Table 1 - Mean comparison of component yield under the effect of densities of corn and Pigweed redroot

\begin{tabular}{|c|c|c|c|c|c|c|c|c|}
\hline \multirow{2}{*}{$\begin{array}{c}\text { Plant density } \\
\left.\text { (plant } \mathrm{m}^{-2}\right)\end{array}$} & GY & BY & $\mathrm{HI}$ & \multirow{2}{*}{ NRE } & \multirow{2}{*}{ NGR } & EL & ED & \multirow{2}{*}{$\frac{100 \mathrm{GW}}{(\mathrm{gr})}$} \\
\hline & \multicolumn{2}{|c|}{$\left(\right.$ ton $\left.\mathrm{ha}^{-1}\right)$} & $(\%)$ & & & \multicolumn{2}{|c|}{$(\mathrm{cm})$} & \\
\hline Corn & $* *$ & $* *$ & $* *$ & $* *$ & & & & \\
\hline 7.5 & $6.66 c$ & $16.52 \mathrm{c}$ & $29.95 a$ & $31.30 \mathrm{ab}$ & $38.00 \mathrm{a}$ & $16.80 \mathrm{a}$ & 5.63 & 18.70 \\
\hline 8.5 & $7.15 b$ & $17.74 b$ & $29.74 a$ & $31.80 \mathrm{a}$ & $37.10 \mathrm{~b}$ & $16.40 \mathrm{ab}$ & 5.62 & 18.50 \\
\hline 9.5 & $7.93 a$ & $19.67 \mathrm{a}$ & $29.70 \mathrm{a}$ & $31.13 b$ & $36.90 \mathrm{~b}$ & $16.20 \mathrm{~b}$ & 5.68 & 18.20 \\
\hline Pigweed & $* *$ & $* *$ & $* *$ & $* *$ & $*$ & $* *$ & & \\
\hline 0 & $9.52 \mathrm{a}$ & $23.62 a$ & $29.30 \mathrm{a}$ & $35.40 \mathrm{a}$ & $37.70 \mathrm{a}$ & $17.60 \mathrm{a}$ & $5.86 a$ & 19.20 \\
\hline 2 & $6.97 \mathrm{~b}$ & $17.19 \mathrm{~b}$ & $29.43 a$ & $30.80 \mathrm{~b}$ & $37.80 \mathrm{a}$ & $17.10 \mathrm{a}$ & $5.79 a$ & 18.60 \\
\hline 4 & $6.89 \mathrm{~b}$ & $17.11 \mathrm{~b}$ & $30.16 a$ & $31.10 \mathrm{~b}$ & $37.70 \mathrm{a}$ & $16.40 \mathrm{~b}$ & $5.56 \mathrm{~b}$ & 18.30 \\
\hline 6 & $6.32 c$ & $15.69 \mathrm{c}$ & $30.50 \mathrm{a}$ & $30.70 \mathrm{~b}$ & $36.60 \mathrm{~b}$ & $15.80 \mathrm{bc}$ & $5.54 b$ & 17.90 \\
\hline 8 & $6.52 \mathrm{c}$ & $16.18 \mathrm{c}$ & $29.60 \mathrm{a}$ & $28.90 \mathrm{c}$ & $36.50 \mathrm{~b}$ & $15.60 \mathrm{c}$ & $5.55 \mathrm{~b}$ & 18.50 \\
\hline
\end{tabular}

$*, * *$ Significantly at the $5 \%$ and $1 \%$ levels of probability. Means followed by same letters in each column are not significant at $5 \%$ (Duncan's Multiple Range Test). GY=Grain yield, BY=Biological yield, HI=Harvest index, NRE=Number of row in Ear, NGR=Number of grain in Ear, EL= Ear length, 100GW= 100 Grain weight, ED=Ea diameter. 
significant effect on other yield components. The increase in the corn plantation density resulted in the increase of the number of grains in a row and an increase of the number of rows. In total, as it can be realized, the effect of Pigweed redroot density on grain yield, biological yield, number of grain in ear, number of rows and number of grain in row, maize diameter, and maize length was significant; the denser the Pigweed redroot became, the lesser the quantity of the mentioned traits became. As a result, the yield loss increased. These results suggest the significance of Pigweed redroot weed control in corn cropping . In addition, it showed that the 100-grains weight and harvest index were not influenced by competition with Pigweed redroot weed; this result is indicative of the ecological rule of survival among plants (Swanton \& Weise, 1991; Hock et al., 2006).

Table 2 - The parameters of the equation for biological and grain yield of corn in competition with Pigweed redroot

\begin{tabular}{|c|c|r|r|c|c|}
\hline $\mathrm{Y}$ & $\begin{array}{c}\text { Plant density } \\
\left(\text { plant } \mathrm{m}^{-2}\right)\end{array}$ & $\mathrm{Y}_{\mathrm{wf}}$ & $\mathrm{I}$ & $\mathrm{A}$ & $\mathrm{R}^{2}$ \\
\hline \multirow{2}{*}{$\begin{array}{c}\text { Grain yield } \\
\left(\mathrm{gr} \mathrm{m}^{-2}\right)\end{array}$} & 7.50 & 874 & 10.82 & 42.40 & 0.87 \\
\cline { 2 - 6 } & 8.50 & 949 & 9.60 & 35.20 & 0.90 \\
\cline { 2 - 6 } & 9.50 & 1,034 & 7.45 & 31.70 & 0.90 \\
\hline \multirow{2}{*}{$\begin{array}{c}\text { Biological } \\
\text { yield } \\
\left(\mathrm{gr} \mathrm{m}^{-2}\right)\end{array}$} & 7.50 & 2,167 & 10.88 & 42.30 & 0.87 \\
\cline { 2 - 6 } & 8.50 & 2,354 & 10.20 & 39.30 & 0.90 \\
\cline { 2 - 6 }
\end{tabular}

Table3 - The parameters of the model of hyperbolic for lost of grain yield (\%) of corn

\begin{tabular}{|c|c|c|c|c|}
\hline $\mathrm{Y}$ & $\begin{array}{l}\text { Plant density } \\
\text { (plant } \mathrm{m}^{-2} \text { ) }\end{array}$ & I & A & $\mathrm{R}^{2}$ \\
\hline \multirow{3}{*}{$\begin{array}{c}\text { Corn in } \\
\text { competition } \\
\text { with Pigweed }\end{array}$} & 7.50 & 10.82 & 52.40 & 0.85 \\
\hline & 8.50 & 9.60 & 46.10 & 0.88 \\
\hline & 9.50 & 7.45 & 35.50 & 0.90 \\
\hline
\end{tabular}

\section{Height}

The results of the experiment indicated that an increase in the density of corn resulted in its height increase (Figure 1). The process of height changes of corn and Pigweed redroot confirmed the fact that the height of Pigweed redroot was higher than that of corn until
70 days after the plantation (Figure 1) and, after that period, the height of corn demonstrated a noticeable boost.

The change of densities of corn and Pigweed redroot had no significant effect on the height of Pigweed redroot (Table 4). Klingaman \& Oliver (1994) reported that an increase in the density of Pigweed redroot from 3.3 to 10 plants/row meter due to a rise of intraspecific conflict resulted in the increase of the height of Pigweed redroot. The lack of influence of corn density on the height of Pigweed redroot might be justified by the higher height of Pigweed redroot compared to corn in the beginning of the growth period (70 days after planting).

Additionally, the studies conducted on the crop plant vs. weed competition indicated the fact that a higher height can compensate for the lower Leaf Area Index (LAI) issue, as weed plants with higher heights and lower LAI have more competitive power for absorbing light compared to a typical crop plant with less height and more LAI (Nassiri \& Kropff, 1997). This fact demonstrated the importance of plant height in competition.

\section{Leaf area index (LAI)}

The increase in the density of Pigweed redroot caused a significant decline in the LAI of corn $(\mathrm{P}<0.01)$ (Table 4). This fact holds true in a way that the increase of Pigweed redroot density from zero to 8 plants in a square meter resulted in a decline of LAI from 5.67 to 4.23. An increase in the corn density led to a

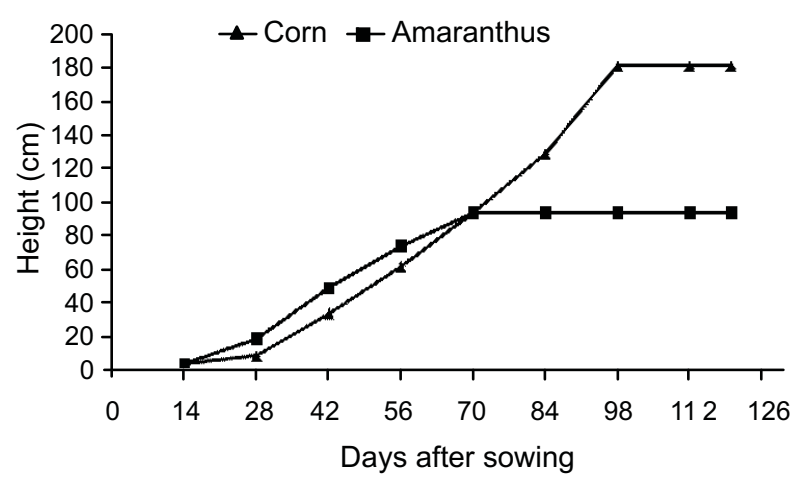

Figure 1 - Height of corn and pigweed redroot in (8.5 plant $\left.\mathrm{m}^{-2}\right)$ Corn and (8 plant $\left.\mathrm{m}^{-2}\right)$ Pigweed redroot in days after sowing.

Planta Daninha, Viçosa-MG, v. 30, n. 3, p. 477-485, 2012 
Table 4 - Comparison of the means growth indexes of Corn \& Pigweed redroot in competition

\begin{tabular}{|c|c|c|c|c|c|c|c|c|c|c|}
\hline \multirow{3}{*}{$\begin{array}{l}\text { Plant density } \\
\frac{\left(\text { plant } \mathrm{m}^{-2}\right)}{\text { Corn }}\end{array}$} & \multirow{2}{*}{\multicolumn{2}{|c|}{$\begin{array}{c}\text { Height } \\
(\mathrm{cm})\end{array}$}} & \multirow{2}{*}{\multicolumn{2}{|c|}{ LAI }} & \multicolumn{2}{|c|}{ CGR } & \multirow{2}{*}{\multicolumn{2}{|c|}{ NAR }} & \multirow{2}{*}{\multicolumn{2}{|c|}{$\frac{\text { LAR }}{\left(\mathrm{m}^{2} \mathrm{gr}^{-1}\right)}$}} \\
\hline & & & & & \multicolumn{2}{|c|}{$\left(\right.$ gr m $^{-2}$ day $\left.^{-1}\right)$} & & & & \\
\hline & Pig & Corn & Pig & Corn & Pig & Corn & Pig & Corn & Pig & Corn \\
\hline 7.5 & 94.92 & 175.0 & $2.39 a$ & $4.60 \mathrm{c}$ & $5.11 \mathrm{a}$ & $22.69 \mathrm{c}$ & $2.14 \mathrm{~b}$ & $4.93 \mathrm{~b}$ & 0.047 & 0.020 \\
\hline 8.5 & 99.08 & 175.6 & $2.24 \mathrm{~b}$ & $4.90 \mathrm{~b}$ & $5.05 \mathrm{a}$ & $24.96 \mathrm{~b}$ & $2.24 \mathrm{a}$ & $4.99 b$ & 0.045 & 0.020 \\
\hline 9.5 & 104.25 & 177.9 & $2.17 \mathrm{c}$ & $5.10 \mathrm{a}$ & $4.89 b$ & $27.79 \mathrm{a}$ & $2.24 \mathrm{a}$ & $5.33 \mathrm{a}$ & 0.045 & 0.180 \\
\hline \multicolumn{11}{|l|}{ Pigweed } \\
\hline 0 & 0 & 174.7 & 0 & $5.67 \mathrm{a}$ & 0 & $33.02 \mathrm{a}$ & 0 & $5.81 \mathrm{a}$ & 0 & 0.017 \\
\hline 2 & 96.56 & 175.8 & $1.95 \mathrm{~d}$ & $5.26 \mathrm{~b}$ & $3.94 \mathrm{~d}$ & $23.53 \mathrm{bc}$ & $2.02 \mathrm{c}$ & $4.64 d$ & 0.049 & 0.022 \\
\hline 4 & 101.44 & 176.0 & $2.05 \mathrm{c}$ & $4.88 \mathrm{c}$ & $4.56 \mathrm{c}$ & $23.98 \mathrm{ab}$ & $2.22 b$ & $4.77 \mathrm{~d}$ & 0.045 & 0.021 \\
\hline 6 & 96.78 & 177.5 & $2.39 b$ & $4.49 \mathrm{~d}$ & $5.32 b$ & $22.70 \mathrm{c}$ & $2.22 b$ & $5.05 \mathrm{c}$ & 0.045 & 0.019 \\
\hline 8 & 102.89 & 177.0 & $2.67 \mathrm{a}$ & $4.23 c$ & $6.24 \mathrm{a}$ & $22.56 \mathrm{c}$ & $2.26 \mathrm{a}$ & $5.33 b$ & 0.042 & 0.018 \\
\hline
\end{tabular}

Means followed by same letters in each column are not significant at 5\% (Duncan's Multiple Range Test). LAI=Leaf area index, CGR=Crop growth rate, LA=Leaf area ratio, NAR=Net assimilation rate.

significant decline of Pigweed redroot LAI $(\mathrm{P}<0.01)$. The increase in the corn density from 7.5 to 9.5 plant $\mathrm{m}^{-2}$ resulted in the decline of the Pigweed redroot LAI from 2.39 to 2.17.

An increase in the Pigweed redroot LAI resulted in the increase of the Partial Leaf Area (Pigweed redroot leaf area/Total Leaf Area) and its amount varied in different corn densities. The maximum Partial Leaf Area (PLA) of Pigweed redroot was $41.5 \%$ at the density of 7.5 plants $\mathrm{m}^{-2}$ of corn; however, it dropped to $36.5 \%$ due to an increase in the corn density to 9.5 plants $\mathrm{m}^{-2}$. Pigweed redroot has a competitive power different from that of corn on account of higher height, more secondary branches, and possessing $\mathrm{C} 4$ photosynthesis pathway. The time for reaching the maximum LAI for Pigweed redroot in monocropping was approximately 70 days after planting and it was nearly 84 days after planting in different corn densities.

The spatial (vertical) distribution of the species leaf area (Figures 2 and 3) showed that the maximum leaf area of corn and the maximum Pigweed redroot leaf area were at the $50-150 \mathrm{~cm}$ of the corn canopy layer and at $40-60 \mathrm{~cm}$ of layer, respectively. The increase in the corn density led to the higher leaf area accretion of both plants in the upper layers of the canopy. Leger \& Schreiper (1989) observed the highest level of leaf area in the lower layer of canopy after 30 days of monocropping, after which the portion of the lower layer decreased and was added to the upper layer through the course of growth.

Density effects on canopy structure, so that with increasing corn density from 7.5 to 9.5 plants $\mathrm{m}^{-2}$, the amount of leaf area index of corn in the layer 50-150 centimeters is more than in the layer $0-50$ centimeters. On the other hand, in the density 9.5 plant per square meter of corn, the amount of Pigweed redroot leaf area in $0-40 \mathrm{~cm}$ of canopy $\mathrm{m}^{-2}$ of corn was next to zero. This fact showed that the increase in the corn density through the decline of each individual Pigweed redroot plant's leaf area led to the decrease of the competitive power of Pigweed redroot. In an experiment, which was conducted with the purpose of comparing the competition between broad-leaved weeds and grasses with the corn plant, $76 \%$ of the corn leaf area and only $23 \%$ of the weed plants biomass were located at one meter above ground level. In these circumstances, the competition of weed plants for absorbing the light that reached the canopy was feeble, since about $75 \%$ of the input radiation was absorbed by the upper layer of corn coating (Barker, 2006).

\section{Relative growth rate}

Relative growth rate of Pigweed redroot was higher than that of corn within 28-42 days after planting; however, after that period of time, no significant differences were observed between corn and Pigweed redroot (Figure 4). 

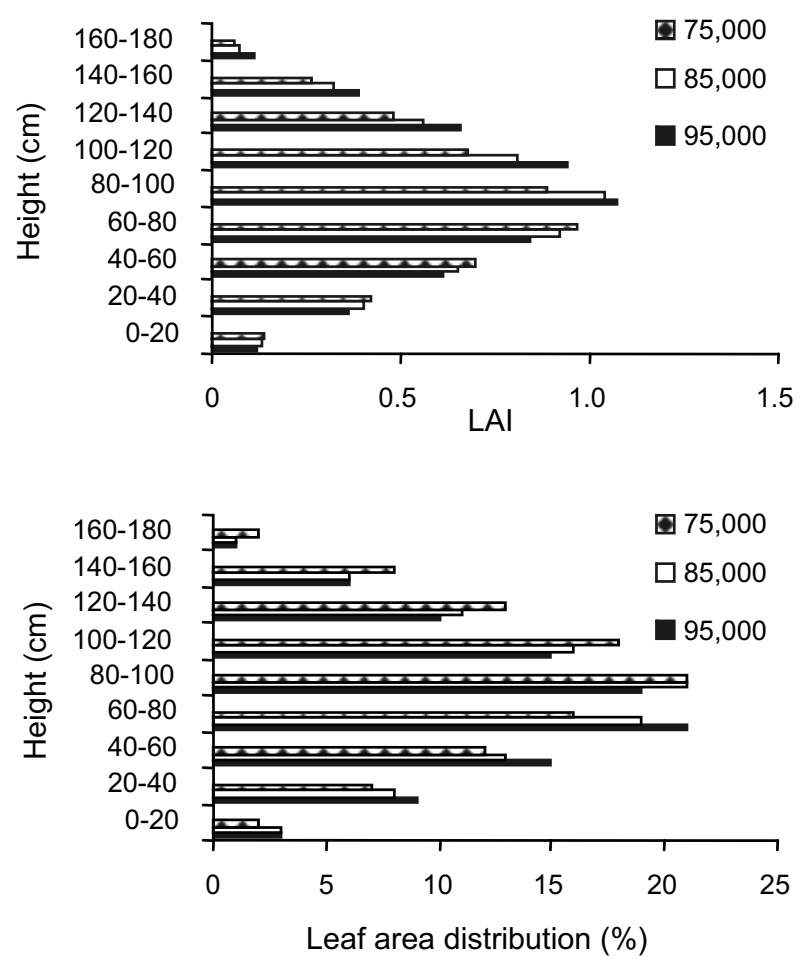

Figure 2 - Layer distribution of Corn leaf area index (LAI) in different densities of Corn (75000, 85000 and 95000 plants ha-1) 84 days after sowing (leaf area maximum of Pigweed redroot).

Relative growth rate of either species was not influenced by the density, which must be related to the fact that the relative growth rate is a genetic trait that differs between various species. A higher relative growth rate of Pigweed redroot within 28-42 days after planting, higher height of Pigweed redroot until 70 days after planting and higher concentration of the leaf area of Pigweed redroot on the upper layers of canopy were the key factors in the competitive dominance of this plant in comparison with corn.

\section{Crop growth rate}

An increase in the density of Pigweed redroot resulted in the significant decrease of the corn growth rate $(\mathrm{P}<0.01)$ (Table 4). That is, the increase in the Pigweed redroot density from $0-8$ plant in square meter led to the decline of the corn growth rate from 33.02 to 22.56 gram m$^{-2}$ day $^{-1}$. Regarding the fact that the crop growth rate depends on the leaf
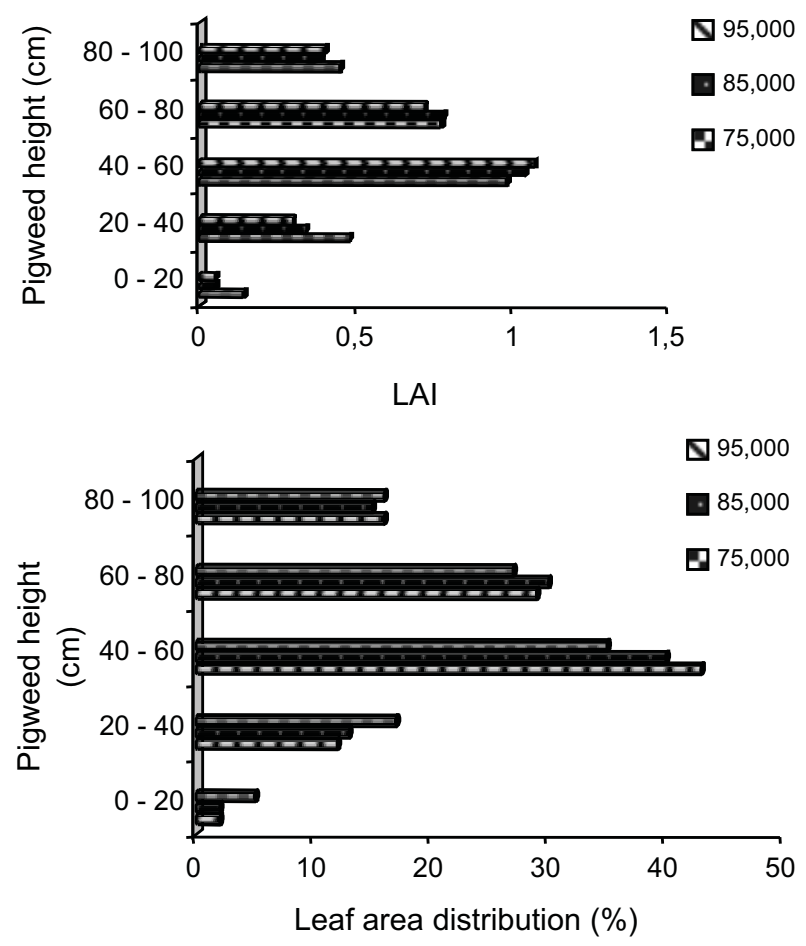

Figure 3 - Layer distribution of Pigweed redroot leaf area index (LAI) in different densities of Corn (75000, 85000 and 95000 plants ha-1) 84 days after sowing (leaf area maximum of Pigweed redroot).

area and photosynthesis of leaf area unit, it can be stated that the main cause of the growth rate reduction is due to the leaf area decrease. The increase in the corn density resulted in a significant reduction of the

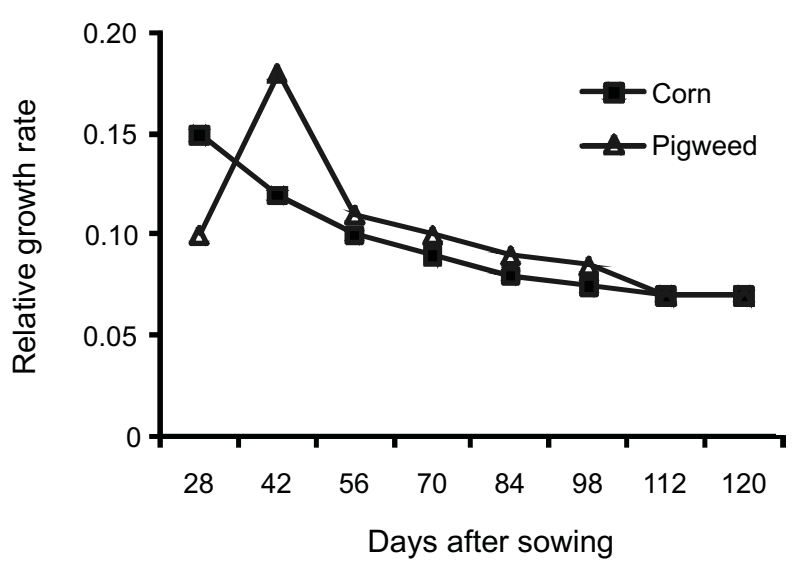

Figure 4 - Corn and Pigweed redroot relative growth rate ( gr gr $^{-1}$ day $^{-1}$ ) in optimum densities (8.5 plant $\mathrm{m}^{-2}$ Corn and 8 plant $\mathrm{m}^{-2}$ Pigweed redroot).

Planta Daninha, Viçosa-MG, v. 30, n. 3, p. 477-485, 2012 
Pigweed redroot growth rate $(\mathrm{P}<0.01)$ (Table 4). The maximum growth rate of Pigweed redroot was observed in all three corn densities within 70 days after planting and the rates in different densities of 7.5, 8.5, and 9.5 corn plants $\mathrm{m}^{-2}$ were equivalent to

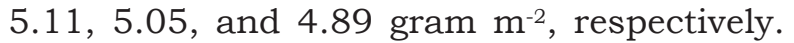
The maximum growth rates of Pigweed redroot in both conditions of monocropping and mixed cropping with corn were observed within 70 days after planting (Figure 5), which

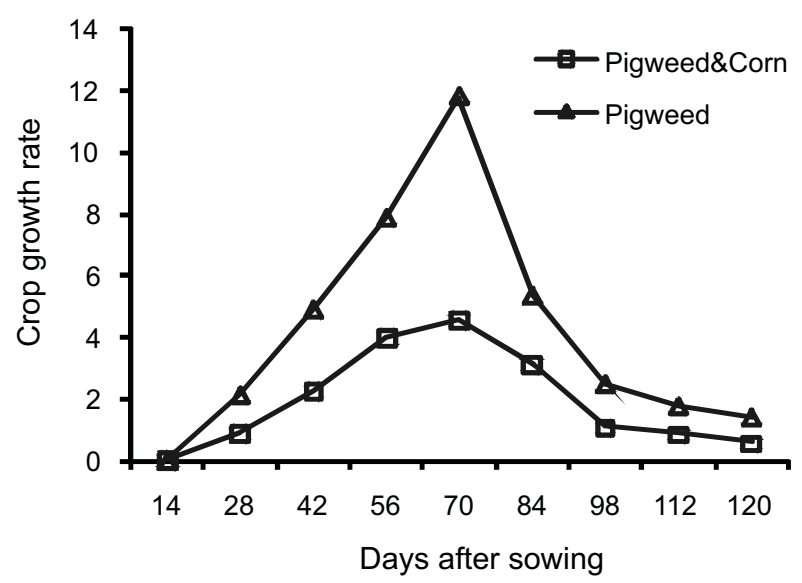

Figure 5 - Pigweed redroot growth rate $\left(\mathrm{gr} \mathrm{m}^{-2}\right.$ day $\left.^{-1}\right)$ in sole cropping and Corn \& Pigweed redroot competition.

were 4.35 and 11.8 gram $\mathrm{m}^{-2}$ day $^{-1}$, respectively.

\section{Economic damage threshold of pigweed redroot in corn yield drop}

The results of the experiment indicated that the increase in the density of Pigweed redroot led to the boost of the yield drop percentage (Figure 6). The maximum yield drop of corn grain in competition with Pigweed redroot was approximately $31.6 \%$, which was observed in the density of 8 plants/row meter of Pigweed redroot and the density of 7.5 plants $\mathrm{m}^{-2}$ of corn.

At first, with the use of Cousins' twoparameter hyperbolic equation, the amounts I and D (Table3) were calculated, and then with the use of O'Donovan's equation, the economic damage threshold of Pigweed redroot in different densities of corn was determined.
The damage threshold density of Pigweed redroot varied in different corn densities between 0.09 to 0.13 plants/row meter and the increase of the corn density resulted in

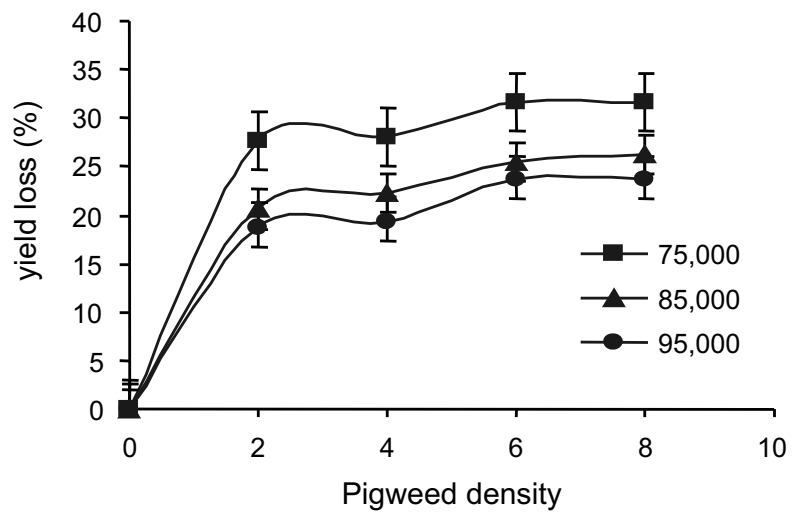

Figure 6 - Effect of Pigweed redroot densities (plant $\mathrm{m}^{-2}$ ) on the loss of corn yield under different crop densities (75000, 85000 and 95000 plants ha ${ }^{-1}$ ).

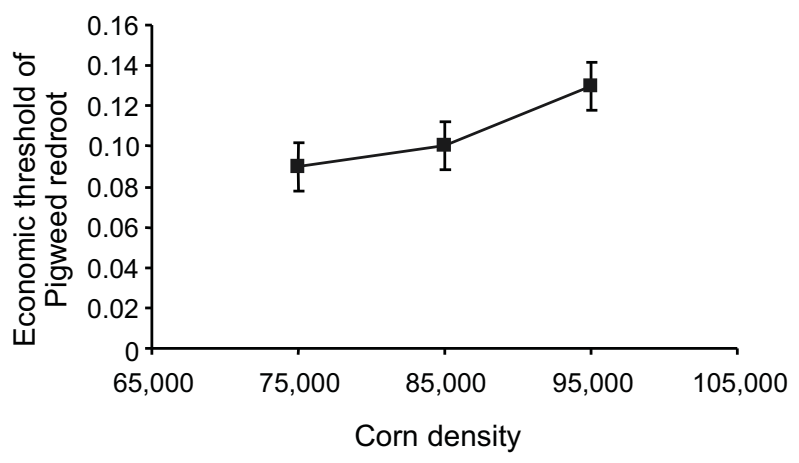

Figure 7 - Effect of corn densities (75000, 85000 and 95000 plants ha-1) on the economic threshold of Pigweed redroot density (plants $\mathrm{m}^{-2}$ ).

the increase of the damage threshold of Pigweed redroot (Figure 7).

The results of this study confirm the negative relationship between Pigweed redroot infestation density and corn yield loss. The results imply that predominance in the temporal and spatial occupancy of the canopy early in the growing season was the most important factor of competitive dominance of Pigweed redroot against corn. This ability is determined by a higher relative growth rate, higher height of plant, and higher concentration of the leaf area in the canopy. The results show evidence of a large potential 
for change in the temporal and spatial occupancy pattern by increasing the crop density. Thus, crop density could be employed as an agronomic tool for enhancing the corn yield and economic damage threshold of Pigweed redroot on corn farms.

\section{LITERATURE CITED}

AGUYOH, J. N.; MASIUNAS, J. B. Interference of Pigweed redroot (Amaranthus retoflexus) with snap beans. Weed Sci., v. 51, n. 2, p. 202-207, 2003.

BARKER, D. C. et al. Effect of nitrogen addition on the comparative productivity of corn and velvetleaf. Weed Sci., v. 54, n. 2, p. 354-363, 2006.

BENSCH, C. N.; HORAK, M. J.; PETERSON, D. Interference of Pigweed redroot,Palmer aamaranth and common water hemp in soybean. Weed Sci., v. 51, n. 5, p. 696-701, 2003.

BROWN, J. H.; PALIYATH, G.; THOMPSON, J. E. Physiological mechanisms of plant senescence.. In: STEWARD, F. C. (Ed). Plant physiology. A treatise, growth and development, New York: Academic Press, 1991. v. 10. p. 227-275.

COUSENS, R. An empirical model relating crop yield to weed and crop density and a statically comparison with other models. J. Agric. Sci., v. 105, n. 3, p. 513-521, 1985.

DAWN, E. N.; HARTZLER, R. G. Influence of corn on common water hemp (Amaranthus rudis) growth and fecundity. Weed Sci., v. 52, n. 1, p. 255-259, 2004.

HARTZLER, R. G.; BATTELS, B. A.; NORDBY, D. Effect of common waterhemp emergence date on growth and fecundity in soybean. Weed Sci., v. 52, n. 2, p. 242-245, 2004.

HOCK, S. M.; KNEZEVIC, S. Z.; MARTIN, A. R. Soybean row spacing and weed emergence time influence weed competitiveness and competitive indices. Weed Sci., v. 54, n. 1, p. 38-46, 2006.

KLINGMAN, T. E.; OLIVER, L. K. Influence of cotton and soybean planting date on weed interference. Weed Sci., v. 42, n. 1, p. 61-65, 1994.

KNEZEVIC, S. Z.; WEISE, S. D.; SWANTON, C. J. Interference of Pigweed redroot in corn. Weed Sci., v. 42, n. 4, p. 568-573, 1994.
KROPFF, M. J.; van LAAR, H. H.; BERGE, H. F. M. (Eds.). ORYZAI: A basic model for irrigated lowland rice production. Los Banos: International Rice Research Institute, 1993. $89 \mathrm{p}$.

JERRY, W. M.; MURRY, D. S.; WESTERMAN, R. B. Palmer Amaranthus (Amaranthus palmer) Effects on the harvest and yield of grain sorghum (Sorghum bicolor). Weed Technol., v. 18, n. 1, p. 23-29, 2004.

JOESPH, N. A.; MASIUNAS, J. B. Interference of pigweed redroot (Amaranthus retoflexus) withsnapbeans. Weed Sci., v. 51, n. 1, p. 202-207, 2004.

LAWRENCE, E. S.; SPRAGUE, C. L. Common waterhemp (Amaranthus rudis) interference in corn. Weed Sci., v. 52, n. 2, p. 359-364, 2004.

LEGER, A.; SCHREIBER, M. M. Competition and canopy architecture as affected by soybean row width and density of Pigweed redroot. Weed Sci., v. 37, n. 1, p. 84-92, 1989.

MASSINGA, R. A.; CURRIE R. S. Impact of Palmer Amaranthus on corn grain yield and quality of forage. Weed Technol., v. 16, n. 3, p. 532-536, 2001.

MASSINGA, R. A.; CURRIE, R. S.; TROOIEN, T. P. Water use and light interception under Palmer Amaranthus and corn competition. Weed Sci., v. 51, n. 4, p. 523-531, 2004.

NASSIRI, M.; KROPFF, M. J. Simulation model for cropweed competition, modified for LAD distribution function and extinction coefficient based on leaf dispersion. Wageningen: Agricultural Wageningen University, 1997.

ODONAVAN, J. T. Quack grass (Elytrgia repens) interference in canola (Brassica compestris). Weed Sci., v. 39, n. 2, p. 392-401, 1991.

SWANTON, C. J.; WEISE, S. F. Integrated weed management. The rational and approaches. Weed Technol., v. 5, n.2, p. 657-663, 1991.

WEAVER, S. E.; KROPPF, M. J.; COUSENES, R. A simulation model of competition between winter wheat and Avena Fatua for light. Ann. Appl. Biol., v. 124, n. 3, p. 315-331, 1994. 